\title{
10. The Australian Labor Party
}

\author{
Elias Hallaj
}

Before I begin the main arguments, I must respond to a few of the biased criticisms made of the Labor Party during the workshop and in some sections of the media.

The Australian Labor Party is not broken. It won the federal election (although the result was not clear until it also won the support of a majority of the Independents and the Greens MP). Of all Australia's numerous political parties (some of which do not exist anymore), the Australian Labor Party is the longest surviving, most democratic, most diverse and most successful. Of course it loses elections as well as winning them and like most major political organisations around the world its membership is slowly shrinking. We need to do more to retain and recruit members; there is no doubt about that. But unlike the grumpy armchair critics and their shrill chorus line, I firmly believe that amongst the membership and leadership of the party, we already have the answers to these universal challenges. We do not need to look too far because some States and Territories are retaining membership and providing a voice for their membership better than others. Rather than look to experiences in the United States or the United Kingdom for all our answers, I will argue we should develop our own answers by recognising existing best practice for recruitment, policy and leadership development, training and campaigning within the ALP.

To the pessimists who falsely claim that Labor is 'broken' or 'has no message', I will politely come back with a simple answer: you are wrong. The Australian Labor Party was founded on principles of social justice and equity and our current policies on education, health care, housing, workplace safety and security (as well as myriad other important policy areas) reflect our desire to make Australia a better place to live for all its citizens.

\section{The Fundamental Challenges Facing Practitioners are Getting Tougher}

For campaign practitioners, it is getting much harder to convey a message. Less people read newspapers, less people watch the news on free-to-air TV each evening, and less people listen to the news or current affairs on radio. 
There has been an explosion of new media, and commercial marketing has overwhelmed our increasingly limited attention spans with a ridiculous amount of information clutter. This clutter is made even more impenetrable by increasing voter cynicism and aversion to political messages and election campaign material.

The increasing cynicism about politics amongst voters is fed on a regular basis by a tabloid media that focuses on conflict, scandal and attention-seeking headlines and images rather than mature and reasoned analysis. This should not be surprising given the fact that the mainstream media is fundamentally profit driven.

Whether it be Sky News or News Limited papers, there is more and more negative coverage with a conservative bias in Australia's mainstream media than there ever has been in the past. ABC News 24 and online sources have very slightly redressed this and turned what was an overwhelmingly large bias in the mainstream media against the ALP into something closer to a very large bias.

The media and the public's very high expectations of modern politicians are often impossible to meet. Although it was fundamentally a good government, Labor's achievements between 2007 and 2010 were selectively overshadowed in the media by short-term challenges and problems. This is not that unusual given the media's focus on conflict over analysis.

And this is by no means unique to Australian politics. There have also been high expectations - impossible to meet expectations - on Barack Obama, Tony Blair and Bill Clinton; all had tough first terms due to very high expectations, both in the media and amongst voters.

The two biggest constraints in any Australian election campaign, for any campaign practitioner, were very apparent in this election: time and money. Neither is likely to change in the short term.

\section{Five Unique, 2010-Specific Factors Affected the Result}

Every local, State-wide and national campaign is unique, and certainly the result of this one is very unusual from a federal perspective, although not so unusual for someone living in Canberra. We now have the first minority Federal Government since 1943. The federal campaign and election in 2010 were unlike any other campaign in recent history. Five unique factors explain the election result 
1. Labor was already on a knife-edge-small margin

2. the leaks

3. a mistaken belief that Labor could not lose

4. Tony Abbott's unexpected success in his small-target strategy

5. third-party (Liberal-front) campaigns against Labor.

\section{1.}

Labor had a majority of only eight seats after the 2007 election and a margin of 1.4 per cent. Several of the Howard Government's 11-year marginal-seat members hung on in tight contests, delivering Labor a smaller majority than might have been expected from its 5.4 per cent two-party preferred swing in 2007.

That 2007 two-party preferred swing to Labor of 5.4 per cent is, amongst postwar swings, beaten only by the 7.4 per cent swing achieved by the Coalition under Malcolm Fraser in 1975, and the 7.1 per cent swing when Gough Whitlam took Labor close to victory in 1969.

There was bound to be a correction, as there was for John Howard in 1998. Seats such as Macarthur, Gilmour, Patterson, Bonner, Dickson, and so on, looked within reach but the tide was already turning against Labor in New South Wales and Queensland in 2008.

While Labor received a massive swing in 2007, the actual buffer or margin was still small because of the large swing required to win government after 2004.

Every first-term government in recent memory has suffered a swing against it in its second election: Whitlam in 1974, Fraser in 1977, Hawke in 1984, and Howard in 1998 all suffered swings against them.

Labor went into this election with a wafer-thin margin, and against the backdrop of the worst global recession in 75 years.

\section{2.}

The five-week campaign had a good start and Labor improved its position in the first week. When the election was called, Labor was ahead and, in the first five or six days of the campaign, we improved in our internal polling. The Nielsen poll after week one had Labor on 54 per cent two-party preferred. 
Then the leaks hit and dominated all media for more than a week. During that period, Labor's vote collapsed and there was nothing Julia Gillard or the campaign could have done to stop that. After week two, Nielsen had Labor's vote down to 48 per cent-a drop of 6 percentage points in a week.

There were three major problems with the leaks

- Labor could not get any message across for more than a week. It did not matter what we did or said, it was just drowned out by the coverage of the leaks

- They caused people to think that Labor was divided

- The nature of the leak stories hurt Labor because they were false stories about Julia Gillard opposing pension increases and paid parental leave.

Labor suspended polling at the end of week two because of swings of about 10 per cent in every seat polled.

Now, we will never know for sure what would have happened if Kevin Rudd had remained leader, but Labor was behind in the polls before the leadership change. We were in danger of seeing a good government lose. The caucus decided that change was necessary to try to stop Tony Abbott from being elected and a return to bad policies such as WorkChoices.

Labor went into this election with a lead, and the leaks in week two caused a large swing against the government. The sudden reappearance of Mark Latham did not help.

\section{3.}

There was a mistaken belief that Labor could not lose and Abbott could not win. This freed up people who wanted to send Labor a protest message.

Only 23 per cent of people the day before the election thought Abbott was a chance of winning. Only half of the Coalition voters thought Abbott had a chance of winning. Not even Liberal Party true believers thought Abbott was a chance.

\section{4.}

Abbott had unexpected success in his small-target strategy. This was made all the worse by the clear run given to Tony Abbott. A leader who had a public reputation as a head-kicker and aggressive combatant suddenly transformed into a kinder, genteel and sensitive new-age guy. His long record in government seemed to be obliterated in the media and, despite Labor's best efforts, he was 
well and truly out of the spotlight. Tony Abbott went into this campaign with nothing but negativity. This follows his record of opposing everything that the Labor government did to strengthen the economy: the economic stimulus, national broadband, improvement in schools and better hospitals.

But we never saw the real Tony Abbott during this campaign; Abbott was scripted, controlled by minders and ran a very disciplined campaign, which aimed to limit or hide his attributes that concern voters. Attributes such as

- speaking without thinking

- his extreme attitudes on women, industrial relations and climate change

- his lack of interest in and understanding of the economy.

By making Abbott a small target, the Liberal campaign was able to make the election more of a referendum on the government's performance.

Also, low expectations of Abbott assisted him during the campaign. People had such low expectations of him, all he had to do was appear half-reasonable and people marked him up for it. At the same time, every criticism he made of Julia Gillard got a run in the media.

Well, you might say, he was not under scrutiny because he was not prime minister, but there are many examples of Opposition leaders under scrutiny (for example, Peter Debnam in 2007 and John Hewson in 1993) and it certainly did not happen to Tony Abbott.

Anyway, it is likely that Abbott's honeymoon might be coming to an end. Although we did not see journalists writing like this during the election campaign, this is what Laurie Oakes posted on the Internet late last year: ' $[\mathrm{t}]$ he jetlag gaffe ${ }^{1}$ was a corker, even by the standards of the old, loose-lipped Abbott we were used to before he took over the Opposition leadership.' And: '[b]ut it was even more startling in light of the iron self-discipline he maintained throughout the election campaign.' And: '[t]o imply that arriving well rested at a conference of British Tories was more important than visiting the Diggers who risk life and limb every day fighting the Taliban was breathtakingly stupid.'

\section{5.}

Several cashed-up groups ran damaging campaigns against Labor and assisted the Liberal Party during the 2010 federal election. The Daily Telegraph (11 August 2010), for example, reported that this election saw the largest number

1 When asked why he declined an invitation to accompany Julia Gillard on a visit to troops in Afghanistan, Tony Abbott initially stated that he had not wanted to arrive jetlagged at the British Conservative Party's annual conference. 
of private firms lobbying during a federal election campaign since the 1970s. Following is a short list of some of the organisations that ran significant antiLabor campaigns during this election.

\section{Alliance of Australian Retailers}

The alliance put out extensive $\mathrm{TV}$, radio and print adverisements depicting small grocers complaining about Labor's excessive taxation, regulations and plain packaging. Here are some typical quotes from the ads: 'The Alliance of Australian Retailers Pty Ltd is fed up with excessive regulation that is making it harder for us to run our businesses.' And: 'In recent times we have been hit with an excessive tax hike that has made our businesses a target for theft and only further fuelled the flourishing black market in tobacco products.'

\section{Association of Mineral Exploration Companies}

The association opposed the government's proposed Minerals Resource Rent Tax (MRRT) with significant TV, print and radio advertisements. The ads argued that 'all Australians' cost of living would rise if the government's tax was implemented'.

\section{Primary Healthcare Australia}

This group campaigned against the government's priorities in health funding and against the government's health reforms using television and radio advertising, running the tag line 'Don't let Labor's health policies be the death of you'. The most vicious of their ads was a radio ad depicting a woman diagnosed with incurable cancer who allegedly could have been saved if Labor had not cut funding.

\section{Australian Fishing Trade Association}

This association asked people to vote against the Greens and the ALP because they would put an end to recreational fishing. They ran expensive newspaper advertisements in Western Australia, the Northern Territory, Queensland and New South Wales, claiming that if Labor and the Greens were elected people would be banned from fishing in many public waters. The ad had a picture of a child with a fishing rod.

\section{Australians for Extradition Justice}

Using well-funded radio advertising, a 'group of businessmen' launched a campaign against the Labor government's new treaty that they said could see Australians extradited to Arab countries and tried under harsh Islamic Sharia law. 
Quote: 'Australians for Extradition Justice believe that as a modern, progressive democracy, Australia should not have extradition treaties with countries that practise torture, or with countries which treat women as property.'

\section{Conclusion}

The 2010 federal election reinforced the view amongst election practitioners that the tasks of governing and campaigning are becoming increasingly challenging due to the increasingly difficult electoral and media environment. The fundamental challenges facing election practitioners are getting tougher, with more cynicism, criticism and constraints, as well as higher expectations, than in previous elections.

In 2010, the federal election also saw the confluence of a unique set of circumstances that challenged the government throughout the election campaign. Before 2010, Labor was already on a knife-edge-small margin. A combination of damaging leaks in the middle of the campaign, a mistaken belief that Labor could not lose, Tony Abbott's unexpected success in his small-target strategy and a series of damaging third-party (Liberal-front) campaigns against Labor all contributed to a significant swing against the government in many electorates. Labor held some of the ground it was predicted to lose in 2010 (for example, holding five seats in Tasmania, and losing only one incumbent in New South Wales), but the unusual minority government that resulted has provided oxygen to an army of armchair critics. The frustrated Abbott-led Opposition still appears to be largely unified and refuses to acknowledge any faults in its record, policies or plans.

Although the formal ALP review of the 2010 campaign is still under way, the ongoing survival of the Gillard Labor Government has confounded a chorus line of conservative critics. The Prime Minister has not taken a step backwards from the constant barrage of unfair criticism thrown at her by Tony Abbott, the Liberal Party and much of the mainstream media.

Unless there is an unforseen by-election that could tip the balance of numbers within the House of Representatives, it appears the Gillard Government will continue to fulfil its legislative agenda. So far, they are winning the majority of votes on the floor of the House of Representatives, and the government's record on infrastructure investments and economic management is strengthening. The next election is still almost two years away - a very long time for Tony Abbott to survive as Opposition Leader. 